\title{
RPL10 Gene
}

National Cancer Institute

\section{Source}

National Cancer Institute. RPL10 Gene. NCI Thesaurus. Code C24748.

This gene plays a role in protein biosynthesis. It is also involved in signal transduction. 